\title{
Knowledge and attitude regarding hepatitis $B$ virus infection and vaccine among hospital patients
}

\author{
SS Katpattil \\ From 3rd International Conference on Prevention and Infection Control (ICPIC 2015) \\ Geneva, Switzerland. 16-19 June 2015
}

\section{Introduction}

Hepatitis B is a potentially life-threatening infection caused by the hepatitis $B$ virus. It is the most serious type of viral hepatitis. About 400 million people have the virus, with most of these people living in Asia. Clearly, this is a significant public health and medical problem.

\section{Objectives}

With this background, the study was conducted to evaluate knowledge and attitude regarding HBV (Hepatitis $B$ virus) infection and its vaccine among the patients attending tertiary care hospital.

\section{Methods}

A Cross-sectional study was done among 856 patients attending a tertiary care hospital, at Mangalore, India, from November 2010 to May 2011after approval from the institutional ethical committee. A pretested structured questionnaire was used to measure the participants' knowledge and attitude regarding HBV (Hepatitis B virus) infection and its vaccine after obtaining informed consent.

\section{Results}

In all, 856 patients (698 male and 158 female) were studied. $50 \%$ of those who were aware had no knowledge about route of transmission, infectivity, or importance of vaccination. Educated individuals were more aware about hepatitis $\mathrm{B}$ vaccine $(\mathrm{P}<0.05)$. The percentage of vaccination was $25 \%$ among study subjects. Lack of awareness was the common reason for non - vaccination (50\%); of them.

\section{Conclusion}

Knowledge of Hepatitis B disease and vaccine was low and misconceptions were common. About One third of the population are vaccinated for hepatitis B. Emphasis

Public Health Dentistry, Yenepoya University, Mangalore, India should especially be laid on awareness campaigns to educate the public that hepatitis $B$ is vaccine preventable disease. Knowledge of the hepatitis B disease may be useful in determining health care interventions strengthening community-based care for patients.

\section{Disclosure of interest}

None declared.

Published: 16 June 2015

doi:10.1186/2047-2994-4-S1-P257

Cite this article as: Katpattil: Knowledge and attitude regarding hepatitis

$B$ virus infection and vaccine among hospital patients. Antimicrobial

Resistance and Infection Control 2015 4(Suppl 1):P257.

\section{Submit your next manuscript to BioMed Central and take full advantage of: \\ - Convenient online submission \\ - Thorough peer review \\ - No space constraints or color figure charges \\ - Immediate publication on acceptance \\ - Inclusion in PubMed, CAS, Scopus and Google Scholar \\ - Research which is freely available for redistribution

